\title{
KIRJOITUS
}

JOONAS RIIKONEN

\section{Häpeä elämänfilosofisena ja teologista ajattelua koskevana kysymyksenä}

Johdanto

Nykyisessä yksilö- ja suorituskeskeisessä yhteiskunnassamme monenlaiset riittämättömyyden kokemukset ovat tyypillisiä peruskokemuksia. Nykytutkimusten valossa tällaisen negatiivisen häpeän jatkuva kokeminen haavoittaa itsetuntoa ja heikentää ihmisen psyykkistä sekä henkistä toimintakykyä; sitä voidaankin pitää merkittävänä uhkatekijänä muun muassa opiskelu- ja työyhteisöjen hyvinvoinnille sekä koko yhteiskunnan elinvoimaisuudelle. Siksi häpeän tunnistaminen ja ymmärtäminen sekä sen haitallisia ilmenemismuotoja tuottaviin tekijöihin vaikuttaminen on tärkeää.

Mistä häpeässä on oikeastaan kysymys ja miksi se on noussut psykologisen ja teologisenkin tutkimuksen suuren mielenkiinnon kohteeksi? Psykologisena kysymyksenä häpeä nousi pintaan viimeistään 1970-luvulla psykoanalyytikko Helen B. Lewisin (1913-1987) havaintojen myötä. Hän teki oleellisen jaottelun syyllisyyden ja häpeän välille: syyllisyys koskettaa jotakin psyykkistä tai konkreettista tekoa kun taas häpeä koskettaa kokemuksellista itseä. Lewisin tärkein havainto oli, että syyllisyys liittyy moraalisesti arvioitavissa olevaan toimintaan, mutta häpeä voi kietoutua ihmisen koko olemukseen. Näiden havaintojen pohjalta alettiin myös ymmärtää sitä, kuinka monisäikeisesti häpeä nivoutuu osaksi ihmisen sosiaalisesti rakentuvaa yksilöllistä identiteettiä ja psykodynamiikkaa (Lewis, 1971).

Sielunhoidollisena ja teologisena kysymyksenä häpeästä kiinnostuttiin 
pastoraalipsykologisessa tutkimuksessa 1990-luvulla. Suomessa uraauurtavaa häpeätutkimusta on tehnyt käytännöllisen teologian professori emeritus Paavo Kettunen. Hän on tuonut tutkimustyössään ansiokkaasti esiin psyykkisen häpeäkokemuksen ainutlaatuisuuden verrattuna syyllisyyteen, joka kuuluu muun muassa omantunnon alueelle. Sen sijaan häpeä kytkeytyy laaja-alaisiin kysymyksiin yksilöllisestä tunne-elämästä, identiteetistä ja itsetunnosta. Esimerkiksi syyllisyyteen auttava anteeksianto ei auta häpeään, koska häpeä edellyttää yksilöllisen tunne- ja kokemusmaailman empaattista kohtaamista. Kyse on sekä uudenlaisten mielensisäisten että ihmisten välisten suhteiden muodostamisesta, joka on kiinteästi sidoksissa itsetuntemuksen sekä psyykkisen kehityksen luonnollisiin, dynaamisiin prosesseihin (ks. Kettunen, 2011, 2014).

\section{Häpeän monisäikeisyys ja kontekstuaalisuus}

Vaikka kiinnostus ja keskustelu häpeään liittyen on kasvanut viime vuosikymmeninä valtavasti, häpeän määrittely ja ymmärtäminen ei ole kuitenkaan helppoa. Eri alojen tutkimusten perusteella häpeästä on piirtynyt kuva moniulotteisena ilmiönä. Siksi häpeää tuleekin tarkastella tietystä näkökulmasta ottaen huomioon niin sen sosiaalinen, kulttuurinen kuin historiallinenkin konteksti (ks. esim. Ikonen \& Rechardt, 1995; Tomkins, 1987).

Sosiokulttuurisen luonteensa vuoksi häpeä vaikuttaa paljolti tiedostamattomasti. Näin ollen häpeän vaikutusten ja merkitysten tunnistaminen on erityisen hankalaa, mutta sitäkin tärkeämpää. Pitkälti pastoraalipsykologisen tutkimuksen ansiosta häpeä on alettu nähdä sielunhoidollisen kontekstin lisäksi myös teologista ajattelua koskevana aihepiirinä, joka vaatii osakseen kriittistä analyysiä (esim. Pattison, 2000).

Ihmisenä olemiseen kuuluvana ilmiönä häpeä kytkeytyy vallitsevaan maailmankatsomukselliseen ja yhteiskunnalliseen eetokseen, joka vaikuttaa kokemukseemme ihmisenä olemisesta. Pohjimmiltaan kyse on siis sosiaalisia rakenteita sekä ajattelu- ja toimintatapoja muokkaavista ihanteista ja arvoista, joiden pohjalta myös häpeän kokeminen viime kädessä kehkeytyy. Niinpä kysymys häpeästä koskettaa meidän jokaisen henkilökohtaista elämänfilosofiaamme ja ihmiskäsitystämme: millaisissa vuorovaikutussuhteissa ja yhteisöissä elämme? Miten muut vaikuttavat kokemukseeni itsestä ja miten itse vaikutan toisiin ihmisiin? 
On siis varsin ilmeistä, että jälkimodernin aikamme kysymys häpeästä on eettis-filosofisesti ja myös systemaattisteologisesti merkittävä ja kiinnostava. Väitöskirjatutkimuksessani tarkastelen 1980-luvun jälkeisessä anglosaksisessa keskustelussa esitettyjä häpeäteologisia ajattelumalleja.

\section{Relationaalisen käänteen merkitys häpeätulkinnoille}

Yksi tutkimusprosessini keskeisimpiä havaintoja on, että teologisen keskustelun ymmärtämiseksi tulee huomioida nykyisen häpeää koskevan tietämyksen kytkeytyminen psykodynaamiseen ihmiskäsitykseen ja moderniin relationaaliseen todellisuuskäsitykseen.

On puhuttu jopa niin kutsutusta "relationaalisesta käänteestä", joka on tapahtunut modernissa länsimaisessa filosofiassa ja ajattelussa 1900-luvun puolivälin jälkeen. Tämä on tarkoittanut sitä, ettei ihmistä tai todellisuuden eri elementtejä voida tarkastella erillisinä tietämisen kohteina vaan suhteiden kautta. Toisin sanoen relationaalisuus on alettu käsittää osaksi substanssien, kuten ihmisen, perimmäistä olemusta eli niiden identiteetti määrittyy suhteessa toisiinsa (ks. Shults, 2003). Filosofisesti tällaisen ajattelun juuret ovat muun muassa personalismissa ja Martin Buberin (1878-1965) ajattelussa, jonka mukaan Jumalan kohtaamisen lisäksi kaikki todellinen kohtaaminen on Minä-Sinä kohtaamista. Näin ollen yksilöllinen Minä kehittyy aina suhteessa Sinään, eikä Minä voi persoonallisessa mielessä olla olemassa ilman vastavuoroista Sinää (ks. Buber, 1995; Jones, 1996).

Ensisijaisesti jälkimodernissa aatteellisessa ilmapiirissä syntynyt uudempi relationaalinen ajattelutapa on luonut pohjaa myös suhdekeskeisille psykoanalyyttisille teorioille. Niiden mukaan yksilöllinen kokemus itsestä muodostuu jatkuvasti yhteydessä sisäisiin mielikuviin ja ulkoisiin vuorovaikutussuhteisiin, jotka ovat merkittävä osa tiedostamatonta minuuttamme. On luonnollista, että tällainen häpeäteorioiden taustalla voimakkaasti vaikuttava relationaalinen ajattelutapa herättää pohtimaan myös teologisen ajattelumme lähtökohtia aiempaa perusteellisemmin ja kriittisemmin.

Tutkimuksessani käy ilmi, että häpeäteologisessa nykykeskustelussa on esitetty useita huomionarvoisia perusteita sille, miksi syyllisyydestä erotettavissa olevalla häpeällä on myös systemaattisteologista relevanssia. Aikaisemmin tämä ajatus on tullut esiin suomalaisessa pastoraalipsykologisessa tutkimuksessa Paavo Kettusen toimesta. Laajemman teologisen tarkastelun myötä 
on esitetty, että häpeän krooniset ja haitalliset muodot asettavat huomattavan haasteen länsimaiselle kristilliselle teologialle ja sen opillisille painotuksille. Siksi on nähty, että on välttämätöntä rakentaa sellaisia teologisia ajattelumalleja, joissa otetaan huomioon nykyinen häpeää koskeva teoreettinen ja empiirinen tietämys.

Pastoraalipsykologien ja muiden teologien kritiikki on kohdistunut erityisesti siihen, että läntisen kristikunnan keskeiset teologit ovat käsitteellistäneet ja tulkinneet ihmisolemuksen ja jumalasuhteen rikkinäisyyttä ensisijaisesti synnin tekemisen, syyllisyyden ja anteeksiannon kautta. Sen sijaan häpeän käsite ei ole saanut opillisiin lausumiin sisältyviä merkityksiä ja siksi se on jäänyt kovin irralliseksi ja epämääräiseksi ei-teologiseksi kategoriaksi (esim. Pattison, 2000).

\section{Häpeän nousu systemaattisteologiseksi kysymykseksi}

Vaikka häpeä on inhimillinen perusemootio ja merkittävä yhteisöjä märittävä tekijä, sen teologinen reflektointi on jäänyt puutteelliseksi. Kun esimerkiksi vanhurskauttamisopin yhteydessä on puhuttu Jumalalle kelpaamattomuudesta, on sitä tulkittu pääsääntöisesti syyllisyyden viitekehyksessä: on ajateltu, että rikkomustensa ja moraalisesti tuomittavan luontonsa vuoksi ihminen on Jumalan edessä syyllinen, syntinen ja kelpaamaton.

Näin ollen esimerkiksi syyllisyyteen keskittyvät synti- ja sovitusopilliset tulkintamallit eivät tarjoa vastauksia häpeään, vaan saattavat jopa tuottaa tarpeetonta häpeää ja hankaloittaa sen tunnistamista ja käsittelyä. Siksi on pyritty korostamaan Jumalan kasvokkaista, vastavuoroista yhteyttä ihmiseen perustana sekä häpeäidentiteetistä eheytymiselle että ihmisen henkiselle hyvinvoinnille ja hengelliselle kasvulle. Häpeän haitallisia muotoja on pidetty esteenä etenkin vastuulliselle toimijuudelle ja läheisille ihmissuhteille, joiden on ajateltu toteutuvan parhaiten juuri dialogisuuteen perustuvassa kanssakäymisessä.

Tutkimukseni osoittaakin, että häpeäteologisen nykykeskustelun sisältämät näkemykset rakentuvat pitkälti vastavuoroista relationaalisuutta painottaville filosofis-teologisille ja psykologisille lähtökohdille. Teologinen häpeäkeskustelu on kuitenkin ollut sisällöltään varsin monenkirjavaa ja siksi siinä esille tulleiden käsitteiden, ajattelurakenteiden ja painopisteiden välillä vallitsee myös huomattavia eroja. Tutkimukseni tarkastelemissa ajattelumal- 
leissa keskeisessä osassa ovat etenkin kolminaisuusoppi, inkarnaatio, ihmisen arvokkuus Jumalan kuvana sekä ihmisen ja Jumalan välisen suhteen vastavuoroisuus. Näiden pohjalta häpeäteologiset konstruktiot painottavat ei-hierarkkisen ja ei-autoritaarisen yhteisöllisyyden sekä yksilöä arvostavan myötätuntoisen kohtaamisen teologisia merkityksiä.

Häpeäteologisten ajattelumallien rakentamisen kannalta keskeisenä haasteena on ollut se, että kristilliseen dogmatiikkaan juurtuneet perinteisemmät lähtökohdat poikkeavat suurestikin modernin teologian ja psykologian edellytyksistä. Teologinen haaste on erityisesti siinä, että historiallisesti katsoen nykyisen häpeäkeskustelun kaltaiset relationaaliset ja psykodynaamiset näkemykset eivät ole olleet kristinuskon opillisen ajattelun perustana. Siksi on luonnollista, että yhteyden luominen perinteisen kristillisen aineksen ja nykyisen häpeää koskevan tietämyksen välille edellyttää teologisen työskentelyn osalta syvällekäyvää ja avarakatseista otetta.

\section{Häpeätutkimukseni keskeisimmät johtopäätökset}

Tutkimusaineistoni pohjalta voikin todeta, että uudemmat suhdekeskeisemmät näkemykset asettavat teologiset ajattelutavat kriittisemmän tarkastelun kohteeksi. Kyse on ensinnäkin sen tiedostamisesta, että opintulkinta ei tapahdu elämänhistoriastamme tai kokemuksistamme irrallaan. Toisekseen kyse on tietoisemmasta pyrkimyksestä ymmärtää kokonaisvaltaisesti teologisen ajattelumme lähtökohtia, merkityksiä, tarkoitusperiä ja käytännön seurauksia. Tällöin keskiössä on oltava pyrkimys selvitellä häpeäkokemusten ja teologisen ajattelun välisiä kytköksiä. Toivonkin tutkimukseni toimivan avauksena laaja-alaisemmalle kristillisen opintulkinnan ja häpeää koskevan tietämyksen väliselle teologiselle keskustelulle.

Etenkin mielen tiedostamattoman ulottuvuuden huomioon ottaminen teologisessa ajattelussa voisi vaikuttaa perusteellisesti tapoihin tulkita ihmisen, synnin ja jumalasuhteen luonnetta. Relationaaliset näköalat syventäisivät laajemminkin esimerkiksi kristillisen jumalakäsityksen kriittistä tarkastelua ja sen uudelleentulkintaa: uusien ajattelumallien lähtökohtana olisi ymmärrys siitä, että käsityksemme ja kokemuksemme Jumalasta sekä itsestämme ovat jatkuvasti keskinäisessä vuorovaikutuksessa dynaamisesti muovautuvia kokonaisuuksia.

Kaiken kaikkiaan tutkimukseni pohjalta vaikuttaa siltä, että häpeää voi- 
daan perustellusti pitää nykyajassamme hyvin merkittävänä teologisena kysymyksenä ja tutkimusaiheena. Oleellista on kuitenkin tiedostaa, ettei häpeä ole pelkästään tai edes ensisijaisesti teoreettisen tarkastelun kohde, joka voitaisiin tyhjentävästi selittää. Sen sijaan häpeä on yleisinhimillinen peruskokemus, joka on osa jokapäiväistä arkielämäämme ja ihmissuhteidemme dynamiikkaa niin hyvässä kuin pahassakin. Sen kokeminen yksilöllisellä tasolla on monenkirjavaa ja vaihtelevaa.

Kaikesta häpeään liittyvästä monisäikeisyydestä huolimatta meistä jokainen on jatkuvasti siihen kytkeytyvien peruskysymysten äärellä: kelpaanko minä, olenko riittävän hyvä opiskelija, työntekijä, johtaja, vanhempi tai lähimmäinen, olenko hyväksytyksi tulemisen arvoinen? Teologisessa kontekstissa kysymykset ovat vieläkin suurempia: kelpaanko Jumalalle, olenko riittävän hyvä kristitty, onko teologinen ajatteluni sopivaa ja totuudellista? Tämänkaltaisia kysymyksiä emme voi väistää, ja siksi meidän tuleekin jatkaa teologisia pyrkimyksiämme tunnistaa, käsitellä sekä ymmärtää häpeää ja siihen liittyviä laajempia kokonaisuuksia.

Lectio praecursoria. Teologian osastolla, Itä-Suomen yliopistolla 4.6.2021.

\section{Kirjallisuus ja lähteet}

Buber, M. (1995). Minä ja Sinä. (suom. Jukka Pietilä). Porvoo: WSOY. (Alkuperäisteos 1923).

Ikonen, P., \& Rechardt, E. (1995). Thanatos, bäpeä ja muita tutkielmia. Helsinki: Nuorisopsykoterapia-säätiö.

Jones, J. W. (1996). Religion and Psychology in Transition. Psychoanalysis, Feminism, and Theology in Transition. New Haven: Yale University Press.

Kettunen, P. (2011). Kätketty ja vaiettu: Suomalainen hengellinen häpeä. Helsinki: Kirjapaja.

Kettunen, P. (2014). Häpeästä hyväksyntään. Helsinki: Kirjapaja.
Lewis, H. B. (1971). Shame and guilt in neurosis. New York, International Universities Press.

Pattison, S. (2000). Shame: Theory, therapy, theology. Cambridge: Cambridge University Press. https://doi.org/10.1017/ CBO9780511612411

Shults, F. L. (2003). Reforming theological anthropology: After the philosophical turn to relationality. Grand Rapids, Michigan: Eerdmans Publishing Company.

Tomkins, S. (1987). Shame. - D. L. Nathanson (toim.), The Many Faces of Shame. New York: Guilford Press, 133-161. 